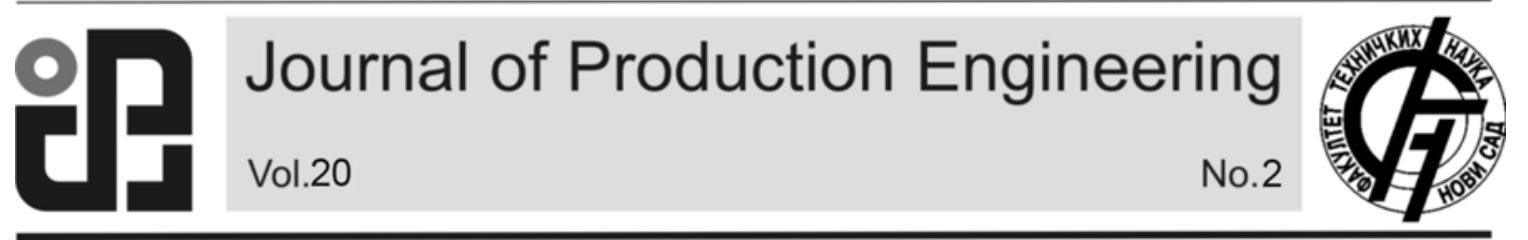

JPE (2017) Vol.20 (2)

Babič, M.

Original Scientific Paper

\title{
NEW METHOD FOR IMAGE ANALYSIS USING NEW ALGORITHM FOR CONSTRUCTING VISIBILITY NETWORK IN 3D SPACE
}

Received: 19 September 2017 / Accepted: 10 November 2017

\begin{abstract}
The objective of this paper is to determine the input-output relationship between parameters of robot laser cell for hardening, topological property of materials after hardening and volume of material using method of intelligent system; neural network, multiple regression and genetic programming. Used was method for calculate volume of materials after robot laser hardening. The effects and interaction terms on different responses of these selected parameters of robot laser cell for hardening have been analysed using neural network, multiple regression and genetic programming. Comparison of all technique of intelligent system was done. Shown was that the neural network givs the best predicted results. The genetic programming model is better than the regression model. Specimen P16 has the most volume after robot laser hardening, that is 77.7\%. Parameter fractal dimension has most impact on regression model and on genetic programming model. It was noticed that topological property of visibility graph effects have considerable influence on the formation of volume, so it cannot be ignored. Used was topological properties of graphs visibility to analyse SEM images of materials after process of robot laser hardening.
\end{abstract}

Key words: image processing, intelligent system, visibility graphs

Novi metod za analizu slike uz upotrebu novog algoritma za konstrukciju mreže vidljivosti u 3D prostoru. Cilj ovog rada je odrediti odnos ulazno-izlaznih parametara robotske laserske ćelije za otvrdnjavanje, topološke osobine materijala nakon otvrdnjavanja i zapremine materijala pomoću metode inteligentnog sistema; neuronske mreža, višestruka regresija i genetsko programiranje. Korišćen je metod za izračunavanje zapremine materijala nakon robotnog laserskog očvršćavanja. Uticaji $i$ uslovi interakcije na različite odgovore ovih odabranih parametara robotske laserske ćelije za otvrdnjavanje su analizirani korišćenjem neuronske mreže, višestruke regresije i genetskog programiranja. Upoređivane su sve tehnike veštačke inteligencije. Pokazano je da neuronska mreža daje najbolje rezultate. Model genetskog programiranja je bolji od modela regresije. Uzorak P16 ima najveću zapreminu nakon robotskog laserskog kaljenja, odnosno 77,7\%. Parametar fraktalne dimenzije ima najveći uticaj na model regresije i model genetskog programiranja. Primećeno je da topološka svojstva grafičkih efekata vidljivosti imaju značajan uticaj na formiranje zapremine, tako da se to ne može zanemariti. Korišćena su topološka svojstava vidljivosti grafova za analiziranje SEM slike materijala nakon procesa robotnog laserskog otvrdnjavanja.

Ključne reči: obrada slike, inteligentni sistem, grafikoni vidljivosti

\section{INTRODUCTION}

Digital images and videos are everywhere these days - in thousands of scientific (e.g., astronomical, bio-medical, mechanical enginering), consumer, industrial, and artistic applications. Moreover they come in a wide range of the electromagnetic spectrum from visible light and infrared to gamma rays and beyond. We will provide a mathematical framework to describe and analyze images [1]. The image processing program explores engineering issues related to the modeling of signals starting from the physics of the problem, developing and evaluating algorithms for extracting the necessary information from the signal, and the implementation of these algorithms on electronic and opto-electronic systems. Specific research areas include filter design, fast transforms, adaptive filters, spectrum estimation and modeling, sensor array processing, image processing, motion estimation from images, and the implementation of signal processing algorithms using appropriate technologies with applications in sonar, radar, speech, geophysics, computer-aided tomography, image restoration, robotic vision, and pattern recognition. Since only the images obtained by a scanning electron microscope (SEM) and a transmission electron microscope (TEM) were used in this work and since both techniques are wellestablished, only a brief introduction is given on the principles and instrumentation of SEM and TEM aiming to show what kind of information is expressed through the images obtained by these techniques. An image in SEM is obtained by scanning the fine focused electron beam over the surface of the specimen and the simultaneous registration of the signals from the detectors. At each point of the specimen the beam dwells for some fixed time during which the electrons of the beam interact with the specimen. A series of image processing technologies and geometric measurement methods is introduced to quantify multiple scale microporosity in images. Computer software developed on the basis of these methods was used to quantify the SEM images of clay samples during shear test. According to the quantification result, 
total pore area and average pore form factor reduce during the test.

Visibility graphs have been extensively studied. Visibility may be dened among the vertices of a polygon, line segments in the plane, or various other geometric objects in two or higher dimensions. Characterizing visibility graphs of simple polygons and nding algorithms to recognize them seem challenging. There is no polynomial-time algorithm known to recognize visibility graphs. Nor is the problem known to be NP-hard, or even in NP. Solution of problem for constructing visibility graphs was presented in [2].

An intelligent system [3] is a machine with an embedded, Internet-connected computer that has the capacity to gather and analyze data and communicate with other systems. Requirements for an intelligent system include security, connectivity, the ability to adapt according to current data and the capacity for remote monitoring and management. Essentially, an intelligent system is anything that contains a functional, although not usually general-purpose, computer with Internet connectivity. An embedded system may be powerful and capable of complex processing and data analysis, but it is usually specialized for tasks relevant to the host machine. The aim of the paper is presenting new method for image analyzing using new method for constructing visibility graphs in 3D space.

\section{MATERIAL PREPARATION AND METHOD}

We made patterns of a standard label on the materials according to DIN standard 1.7225. We hardened tool steel with the laser temperature $\mathrm{T} \in$ $[1000,1400]^{\circ} \mathrm{C}$ and different speed $\mathrm{v} \in[2,5] \mathrm{mm} / \mathrm{s}$. In all these attempts we have made picture of microstructure (Fig. 1).

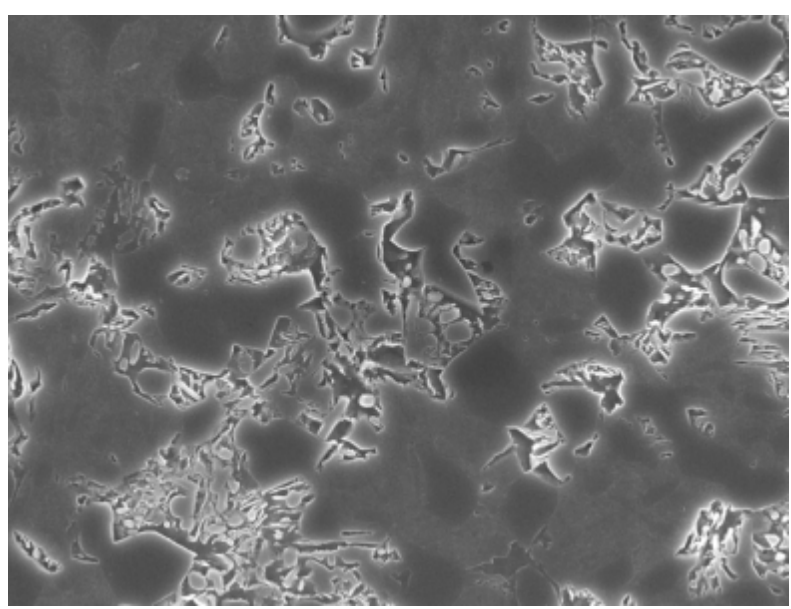

Fig. 1. Microstructure of robot laser hardened specimens

Detailed characterization of their microstructure before and after surface modifications was conducted using a field emission scanningel ectronmicroscope (SEM), JEOL JSM-7600F. The SEM pictures wereconverted into binary images, from which we calculated the density of visibility graph for 3D space, and calculate volume. For each $(x, y, z)$ we use only $z$ coordinate. Coordinate $\mathrm{z}$ have maximal value 256 .
Also, we calculate volume of robot laser hardened specimens with (1)

$$
V=\frac{z_{1}+z_{2}+\ldots+z_{n}}{256 \times n}
$$

for all $n$.

For image analyze, we use method of visibility graph. We use new method for constructing visibility graphs in 3D space. We calculate topological property; namely density of $3 \mathrm{D}$ visibility graphs.

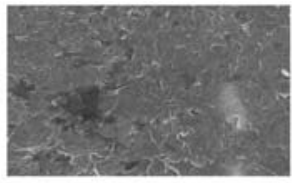

SEM IMAGE

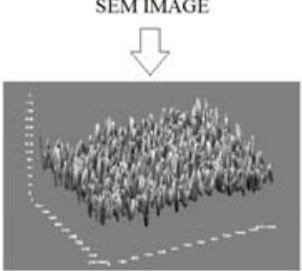

3D GRAPH OF SEM IMAGE

USING ALGORITH FOR CONSTRUCTING VISIBILITY GRAPHS IN 3D SPACE

CALCULATING TOPOLOGICAL PROPERTY OF VISIBILITY GRAPHS IN 3D SPACE Fig. 2. Intelligent system model

To model the results, we used the intelligent system methods, i.e. the genetic programming method, neural network and multiple regression.

Genetic programming [4] is known to be capable of creating designs that satisfy prespecified high-level design requirements for analog electrical circuits and other complex structures. However, in the real world, it is often important that a design satisfy various nontechnical requirements. One such requirement is that a design not possess the key characteristics of any previously known design. Traditional genetic programming ignores the meaning of programs, as the search operators it employs act on their syntactic representations, regardless of their semantics. E.g., subtree swap crossover is used to recombine functions represented as parse trees, regardless of trees repres enting boolean expressions, mathematical functions, or computer programs.

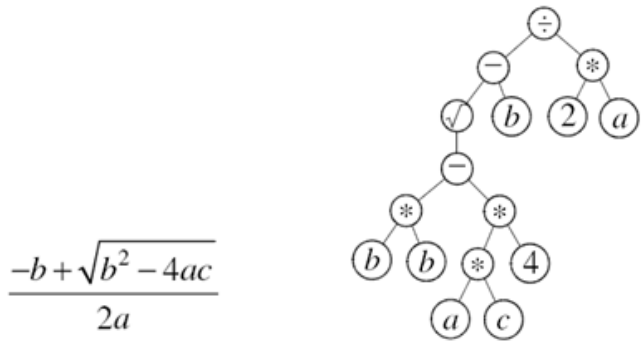

Fig. 3. Randomly generated mathematical model of genetic programming 
These deep learning techniques are based on stochastic gradient descent and backpropagation, but also introduce new ideas. These techniques have enabled much deeper (and larger) networks to be trained - people now routinely train networks with 5 to 10 hidden layers. The idea is to take a large number of handwritten digits, known as training examples, and then develop a system which can learn from those training examples. In other words, the neural network [5] uses the examples to automatically infer rules for recognizing handwritten digits. Furthermore, by increasing the number of training examples, the network can learn more about handwriting, and so improve its accuracy. So while I've shown just 100 training digits above, perhaps we could build a better handwriting recognizer by using thousands or even millions or billions of training examples.

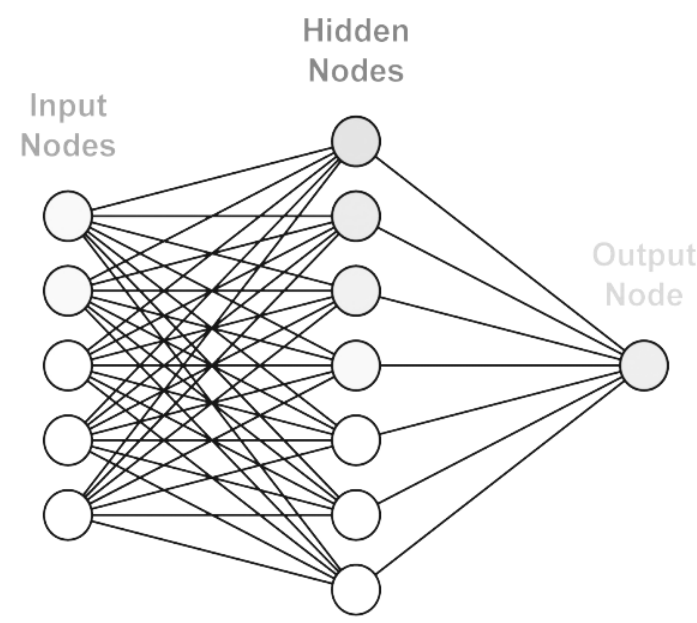

Fig. 4. General multi-layer neural network system

Multiple regression [6] is a flexible method of data analysis that may be appropriate whenever a quantitative variable (the dependent or criterion variable) is to be examined in relationship to any other factors (expressed as independent or predictor variables). Relationships may be nonlinear, independent variables may be quantitative or qualitative, and one can examine the effects of a single variable or multiple variables with or without the effects of other variables taken into account (Cohen, Cohen, West, \& Aiken, 2003). Multiple regression is an extension of simple linear regression. It is used when we want to predict the value of a variable based on the value of two or more other variables. The variable we want to predict is called the dependent variable (or sometimes, the outcome, target or criterion variable). The variables we are using to predict the value of the dependent variable are called the independent variables (or sometimes, the predictor, explanatory or regressor variables). A multiple regression equation for predicting $\mathrm{Y}$ can be expressed a follows:

$\mathrm{Y}=\mathrm{b}+\mathrm{b}_{1} \mathrm{X}_{1}+\mathrm{b}_{2} \mathrm{X}_{2}+\ldots+\mathrm{b}_{\mathrm{m}} \mathrm{X}_{\mathrm{m}}+\mathrm{c}$,

where $\alpha_{i}$ is the corrected effect on $y$ given that you are in group $i$ (corrected in the sense that the covariates $\mathrm{x}_{1}$, $\ldots, \mathrm{x}_{\mathrm{m}}$ are taken into account).

\section{RESULTS AND DISCUSSION}

In Table 1, the parameters of hardened specimens that impact on volume are presented. We mark specimens from $\mathrm{P} 1$ to $\mathrm{P} 21$. Parameter $\mathrm{X}_{1}$ presents the parameter of temperature in degree of Celsius [C], $\mathrm{X}_{2}$ presents the speed of hardening $[\mathrm{mm} / \mathrm{s}]$ and $\mathrm{X}_{3}$ presents density of visibility graphs in $3 \mathrm{D}$ space. The last parameter $\mathrm{Y}$ is the volume of therobot laserhardened specimens. Table 2 presents experimental and prediction data regarding the volume of laser hardened robot specimens. In Table 2 present symbol $\mathrm{S}$ name of specimens, E experimental data, NM1 prediction with neural network with $30 \%$ learn set, NM2 prediction with neural network with $50 \%$ learn set, NM3 prediction with neural network with method one live out, $\mathrm{R}$ prediction with regression and GP prediction with genetic programming. In Table 1, we can see that specimen P17 has the largest density of visibility graphs in $3 \mathrm{D} ; 0.2832$, thus specimen $\mathrm{P} 17$ have most complex graph. Specimen P16 has maximal volume after hardening, that is $77,7 \%$. The measured and predicted volume of robot laser hardened specimens is shown in the graph in Fig. 5. The genetic programming model is presented on Fig. 3. Under model of genetic programming is presented model of regression. The genetic programming model presents a $14,14 \%$ deviation from the measured data, which is less than the regression model, which presents a $31,07 \%$ deviation. The best neural network NN3 present 5,22\% deviation from the measured data. Neural network NN1 present $40,36 \%$ deviation from the measured data and NN2 present $26,49 \%$ deviation from the measured data.

\begin{tabular}{lllll}
\hline $\mathrm{S}$ & $\mathrm{X}_{1}$ & $\mathrm{X}_{2}$ & $\mathrm{X}_{3}$ & $\mathrm{Y}$ \\
\hline P1 & 1000,0 & 2,0 & 0,1936 & 28,0 \\
\hline P2 & 1000,0 & 3,0 & 0,2208 & 20,6 \\
\hline P3 & 1000,0 & 4,0 & 0,2144 & 25,4 \\
\hline P4 & 1000,0 & 5,0 & 0,2256 & 22,5 \\
\hline P5 & 1400,0 & 2,0 & 0,2445 & 22,9 \\
\hline P6 & 1400,0 & 3,0 & 0,2221 & 19,3 \\
\hline P7 & 1400,0 & 4,0 & 0,2036 & 13,2 \\
\hline P8 & 1400,0 & 5,0 & 0,2096 & 21,0 \\
\hline P9 & 1000,0 & 2,0 & 0,2352 & 24,0 \\
\hline P10 & 1000,0 & 3,0 & 0,2288 & 27,5 \\
\hline P11 & 1000,0 & 4,0 & 0,2144 & 28,7 \\
\hline P12 & 1000,0 & 5,0 & 0,2352 & 23,7 \\
\hline P13 & 1400,0 & 2,0 & 0,2208 & 26,3 \\
\hline P14 & 1400,0 & 3,0 & 0,232 & 22,1 \\
\hline P15 & 1400,0 & 4,0 & 0,1984 & 20,3 \\
\hline P16 & 1400,0 & 5,0 & 0,1904 & 77,7 \\
\hline P17 & 800,0 & 0,0 & 0,2832 & 15,3 \\
\hline P18 & 1400,0 & 0,0 & 0,2688 & 31,8 \\
\hline P19 & 2000,0 & 0,0 & 0,2416 & 36,9 \\
\hline P20 & 950,0 & 0,0 & 0,2128 & 70,8 \\
\hline P21 & 850,0 & 0,0 & 0,208 & 43,9 \\
\hline Ta6 & Paramer \\
\hline
\end{tabular}

Table 1. Parameters of hardened specimens 


\begin{tabular}{lllllll}
\hline S & E & NN1 & NN2 & NN3 & R & GP \\
\hline P1 & 28,0 & 27,50742 & 26,01407 & 27,90347 & 44,37732 & 24,2895 \\
\hline P2 & 20,6 & 23,00408 & 24,39492 & 22,52183 & 29,17192 & 23,1765 \\
\hline P3 & 25,4 & 22,33313 & 23,38383 & 26,81549 & 27,6009 & 23,1482 \\
\hline P4 & 22,5 & 24,05944 & 22,27488 & 24,59062 & 18,88807 & 23,2812 \\
\hline P5 & 22,9 & 22,20732 & 22,13044 & 22,17005 & 24,27785 & 22,8552 \\
\hline P6 & 19,3 & 18,75935 & 21,39192 & 19,22296 & 29,1994 & 21,562 \\
\hline P7 & 13,2 & 16,9911 & 20,66272 & 14,00208 & 32,53838 & 20,432 \\
\hline P8 & 21,0 & 18,27011 & 19,78675 & 20,92132 & 25,93563 & 20,9101 \\
\hline P9 & 24,0 & 26,22141 & 25,34777 & 25,65762 & 27,49666 & 23,6286 \\
\hline P10 & 27,5 & 23,22075 & 24,29008 & 25,78809 & 25,92564 & 23,3662 \\
\hline P11 & 28,7 & 22,33313 & 23,38383 & 26,81549 & 27,6009 & 23,1482 \\
\hline P12 & 23,7 & 24,68148 & 22,20033 & 14,88504 & 14,99253 & 23,6427 \\
\hline P13 & 26,3 & 22,29818 & 22,38205 & 27,23018 & 33,89496 & 21,3368 \\
\hline P14 & 22,1 & 19,0925 & 21,30572 & 23,30462 & 25,18213 & 22,195 \\
\hline P15 & 20,3 & 16,6859 & 20,71165 & 22,5824 & 34,64846 & 20,0704 \\
\hline P16 & 77,7 & 16,76278 & 19,93818 & 78,04819 & 33,7267 & 19,5703 \\
\hline P17 & 15,3 & 38,70168 & 28,79808 & 15,34632 & 16,07756 & 15,3229 \\
\hline P18 & 31,8 & 34,44064 & 23,92898 & 31,92222 & 22,75336 & 32,6352 \\
\hline P19 & 36,9 & 26,54524 & 20,1595 & 36,94508 & 34,62322 & 35,9125 \\
\hline P20 & 70,8 & 45,32039 & 28,75148 & 70,39741 & 44,85295 & 23,3618 \\
\hline P21 & 43,9 & 46,97915 & 29,80684 & 44,0274 & 46,66197 & 44,6988 \\
\hline Tab & Exp &
\end{tabular}

Table 2. Experimental and prediction data

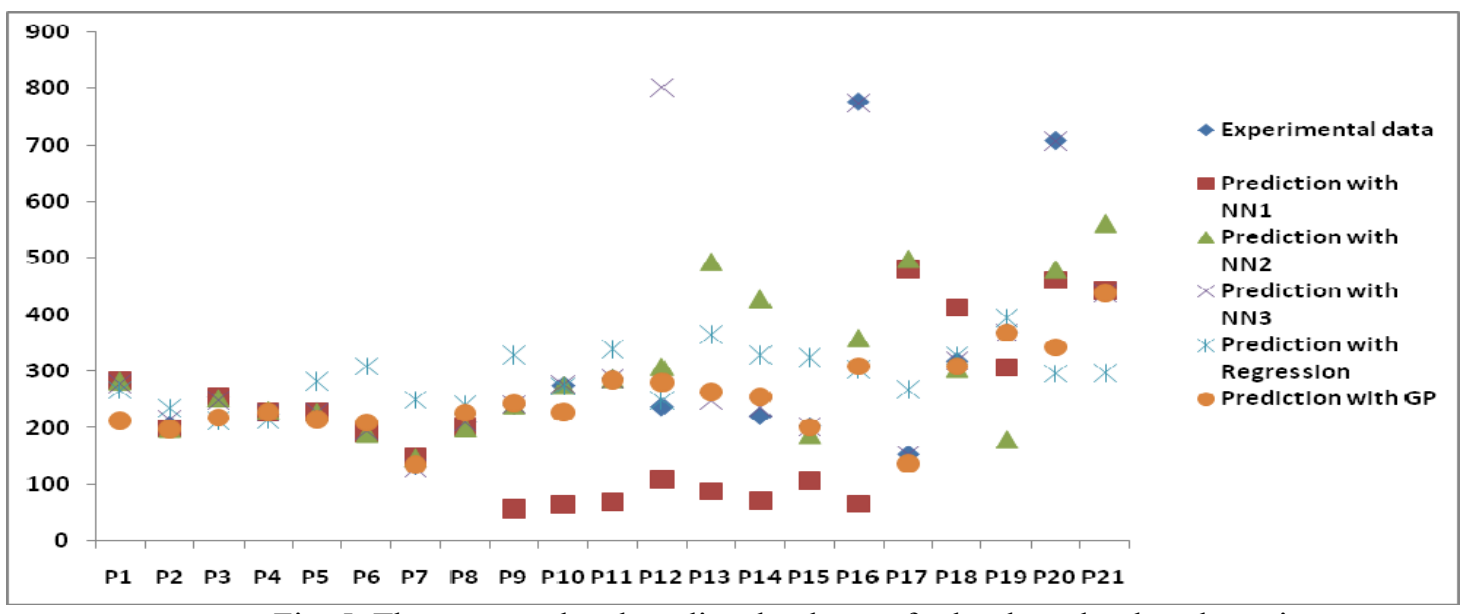

Fig. 5. The measured and predicted volume of robot laser hardened specimens

Model of genetic programming

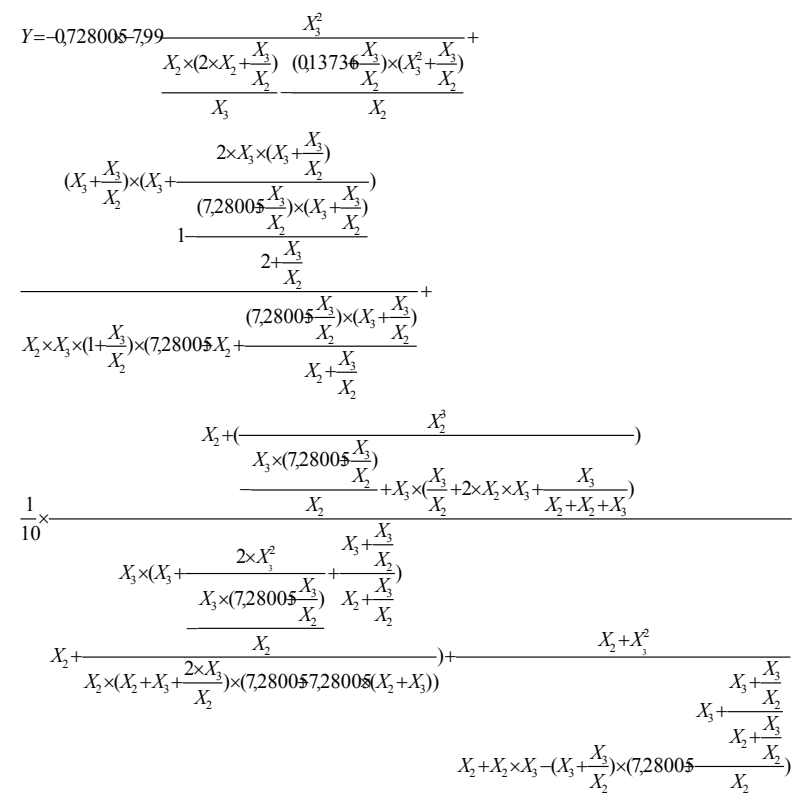

Model of regression

$$
\begin{aligned}
& Y=129,885900+0,00138749 \times \mathrm{X}_{1}- \\
& 4,16804262 \times \mathrm{X}_{2}-405,785107 \times \mathrm{X}_{3}
\end{aligned}
$$

A statistically significant relationship was found between volume, the parameters of the robot laser cell and image analysis with new method of graph theory, especially in visibility graphs in 3D space. In addition, image analysis of SEM images of robot laser hardened specimens is an interesting approach. Specimen P16 has the most volume after robot laser hardening, that is $77,7 \%$. Parameter $\mathrm{X}_{3}$ (fractal dimension) has most impact on Regression model and on genetic programming model. We use method of intelligent systems; genetic programming, neural network and multiple regression to predict volume of robot laser hardened specimens. We show that the neural network give us the best predicted results. The genetic programming model is better than the regression model. 


\section{CONCLUSSION}

In the paper we present the use of an intelligent system method, genetic programming, neural network and multyple regression to predict the volume of hardened specimens, with new method of constructing visibility graphs in $3 \mathrm{D}$ space. We describe a method of the visibility graph in a $3 \mathrm{D}$ space to analise complexity of the robot-laser-hardened specimens. The main findings can be summarised as follows:

1. We describe the volume of the hardened specimens by using the topological properties of the visibility graphs in a $3 \mathrm{D}$ space.

2. We describe the relationship between volume and the parameters of the robot-laser cell by using the topological properties of the 3D visibility graphs. This finding is important with regard to certain alloys that are hard to mix because they have different melting temperatures; however, such alloys have better technical characteristics. By varying different parameters (e.g., temperature), the robotlaser cells produce different patterns with different topological properties of the 3D visibility graphs.

3. To predict the volume of the hardened specimens, we use a neural network, genetic algorithm and multiple regression.

4. Using the presented intelligent system we increase production of the laser-hardening process by decreasing time of the process and increase the topographical property of materials.

\section{REFERENCING}

[1] R. Kumar, M. Rattan. Analysis of various quality metrics for medical image processing. Int. J. Adv. Res. Comput. Sci. Software Eng., 2 (2012), pp. 137-144.

[2] Matej Babič. Doctoral Thesis. 2014.

[3] Beverly Woolf, "Intelligent Tutoring Systems: A Survey," in Exploring Artificial Intelligence: Survey Talks from the National Conferences on Artificial Intelligence, ed. by Howard E. Shrobe and the American Association for Artificial Intelligence (San Mateo, CA.: Morgan Kaufmann, 1988), 1-43.

[4] R. Koza. Course Notes for Genetic Algorithms and Genetic Programming. Spring, (2002).

[5] Graves, Alex; and Schmidhuber, Jürgen; Offline Handwriting Recognition with Multidimensional Recurrent Neural Networks, in Bengio, Yoshua; Schuurmans, Dale; Lafferty, John; Williams, Chris K. I.; and Culotta, Aron (eds.), Advances in Neural Information Processing Systems 22 (NIPS'22), December 7th-10th, 2009, Vancouver, $B C$, Neural Information Processing Systems (NIPS) Foundation, 2009, pp. 545-552.

[6] P. Thamilarasi, S. Ragunathan, E. Mohankumar. Development of empirical models for prediction of weld bead geometry in robotic - GMAW. Journal of Achievements in Materials and Manufacturing Engineering. Volume (67), Issue 2, (2014), 72-85.

Author: Dr. Matej Babič, Bs.M.

Jožef Stefan Institute, Slovenia,

E-mail: babicster@gmail.com 